\title{
Wagner's Law Revisited: Cointegration and Causality tests for New Zealand
}

\author{
Saten Kumar, Don Webber and Scott Fargher \\ Department of Business Economics, Auckland University of Technology, New Zealand
}

\begin{abstract}
Wagner's Law states that the share of government expenditure in GNP will increase with economic development; many associated empirical studies substitute GNP with GDP. This paper presents an empirical investigation into the validity of Wagner's Law for New Zealand over the period 19602007 and compares the results obtained using these two measures of output. Application of the autoregressive distributed lag bounds test suggests a cointegrating relationship between either output measure and the share of government spending, and further application of General to Specific, Engle and Granger, Phillip Hansen's Fully Modified Ordinary Least Squares and Johansen's time series techniques illustrate statistical robustness and an income elasticity between 0.56 and 0.84 . The results suggest that output measures Granger-cause the share of government expenditure in the long run, thereby providing support for Wagner's Law, and these results are stable irrespective of the chosen output measure.
\end{abstract}

Keywords: Government spending; GNP; GDP; Cointegration; Granger causality

JEL: C22; H50

Acknowledgements: The authors are grateful to Tsangyao Chang, Anisul Islam and Peter Howells for comments on earlier drafts. All errors are the authors' responsibility.

Corresponding author: Don Webber, Department of Business Economics, Auckland University of Technology, New Zealand. Email: Don.Webber@aut.ac.nz 


\section{Introduction}

Wagner's (1883) Law predicts that government expenditure will increase at a faster rate than the growth of GNP and therefore, as an economy develops, the share of GNP devoted to government expenditure should increase over time. Wagner's classical theory posits this is due to social, administrative and welfare issues which increase in need and complexity as an economy develops, implying that the direction of causation is from GNP to the share of government expenditure. But an alternative hypothesis, postulated by Keynes (1936), is that fiscal stimuli are occasionally required to boost aggregate demand and GNP, especially in times of recession. This line of thought exemplifies that the direction of causality can be from government spending to GNP.

The relationship between government spending and national output is important for many policy-related issues. For instance, recessionary (expansionary) periods impede (enhance) central authorities' abilities to stimulate their economy via fiscal measures unless the share of government spending to GNP increases (reduces). Long run estimates of the relationship between government expenditure and national output would permit the identification of a benchmark against which one can identify the fiscal policy stance adopted by particular governments. The government spending and national output relationship is also relevant for the debate on the sustainability of public finances, especially during the phase when governments struggle to restrain government spending. Therefore, the identification of this relationship provides a theoretical framework against which to formulate and judge fiscal policy adjustment plans concerning medium term budgetary objectives.

Although Wagner's Law originally concerned the relationship between government expenditure and GNP, much empirical work examines the relationship between government expenditure and GDP; ${ }^{1}$ the strength and similarity of results generated with either GNP or GDP will depend on the importance of the international market to the growth of the economy; empiricists should choose wisely between these two measures of national output.

New Zealand has been a highly protected and regulated economy at least since the first half of the $20^{\text {th }}$ Century with the introduction of social security systems, industrial regulation and heavily regulated imports. But since 1984 government subsidies have been eliminated, marginal tax rates have been reduced and controls on interest rates, wages and prices have been removed. Deregulation of government-owned enterprises in the 1980s and 1990s reduced the government's role in the economy that arguably led to higher rates of unemployment (and increased welfare spending), although this rate has reduced in recent years to a current low level of about 3.5 percent. Nevertheless the current account deficit, which stood at more than 6.5 percent of GDP in 2000, is on the increase and stood at 9 percent of GDP in 2006. New Zealand's volatile export sector and decreases in the New Zealand dollar's exchange rate may narrow the deficit.

Motivated by these policy implications and New Zealand's recent economic experiences, this paper seeks to identify the validity of Wagner's Law for New Zealand using a number of alternative estimation methods and two output measures (GNP and GDP). Changes in New Zealand's openness and internal economic structures make her a natural case study on which to test Wagner's Law and to identify whether the relationship exists with GNP and/or GDP. Utilizing data over the 1960-2007 period, this paper i) presents estimates of the long run cointegrating relationship between government spending and GNP (and GDP) using the autoregressive distributed lag bounds test technique (Pesaran et al., 2001) and ii) identifies the causal relationship between government spending and GNP (and GDP) using

1 Arpaia and Turrini (2008) outline Wagner's Law in the context of EU countries. 
the Granger causality tests. For comparison of results, we also employ the General to Specific (GETS), Engle and Granger (EG), Phillip Hansen's Fully Modified Ordinary Least Squares (FMOLS) and Johansen's time series techniques. It is, to the knowledge of the authors, the first paper to conduct such a thorough study of a national economy that has experienced turbulent times in recent decades.

This paper has the following structure: Section 2 briefly discusses trends in government spending and national income in New Zealand. Section 3 summarizes studies related to Wagner's Law. Section 4 and 5 detail the methodology and empirical results, respectively. Section 6 concludes.

\section{Trends in government spending and national income in New Zealand}

The variables used in this study contain annual time series data for the period 1960-2007 and can be sourced from the International Financial Statistics CD-ROM (IFS, 2008). Trends in broad functional areas of government spending in OECD countries are discussed by Tanzi and Schuknecht (2000) and Claus et al. (2008) and Barker et al. (2008) elaborate on fiscal policy issues in New Zealand. New Zealand's Treasury (2008) finds that the three largest areas of government expenditure during the 2007/2008 financial year was social security and welfare $(\$ 21,509 \mathrm{~m})$, health $(\$ 10,809 \mathrm{~m})$ and education $(\$ 10,397 \mathrm{~m})$. Public debt in New Zealand stood at 23 percent of GDP in 2008 and although this is lower than the UK and USA it is slightly higher than Australia, which is New Zealand's main trading partner, and any further increase would imply that future government spending may be directed towards debt servicing (World Factbook, 2009). Between the early-1980s to mid-1990s real government expenditure moderately declined due to privatizations, subcontracting of services to the private sector and reductions in defense spending.

Table 1 presents average growth rates of real government expenditure $(\Delta \ln G)$, real GDP $(\triangle \ln G D P)$, the share of real government expenditure in $G D P(\triangle \ln G G D P)$, real GNP $(\triangle \ln G N P)$ and the share of real government expenditure in $G N P(\triangle \ln G G N P)$ for the whole (1960-2007) and for decade sub-periods.

\{Insert Table 1 about here $\}$

There have been trend increases of $G, G D P, G G D P, G N P$ and $G G N P$ over the entire time period, albeit with temporal fluctuations. Government expenditure growth varied from a high of 7.1 percent in the 1970s (mainly due to a combination of expansionary fiscal policy and high rates of industrial assistance following the oil price shocks and difficulties in international markets for agricultural commodities (Treasury, 2008)) to a low of 1.8 percent in the 1990s. The growth rate of GDP accelerated over the period 1960-2007, which can be attributed to i) economic reforms that began in the mid-1980s and ii) the late 1990s global demand boom which led to New Zealand's longest-ever sustained period of growth (19992007; Treasury, 2009). Growth rates of shares of government expenditure in GDP and in GNP have reduced dramatically since the 1980s although they have increased slightly since the millennium, which is a reflection of the governments' recent controls over expenditures and a desire to reduce government debt (Barker et al., 2008).

\section{Empirical literature to date}

Wagner's Law has been tested empirically for various countries using cross-section, time series and panel data methods, and results vary considerably from country to country with 
some supportive ${ }^{2}$ and some opposing ${ }^{3}$ evidence. Recent empirical studies on Wagner's Law have been surveyed critically by Peacock and Scott (2000). Although there has been no country-specific study of this Law for New Zealand, some studies have examined New Zealand's economy when pooled with other country data by estimating one or more of the following equations:

$$
\begin{aligned}
& \ln G_{i t}=\alpha_{i}+\beta_{i} \ln G D P_{i t}+\varepsilon_{i t} \\
& \ln G_{i t}=\alpha_{i}+\beta_{i} \ln G D P p c_{i t}+\varepsilon_{i t} \\
& \ln G p c_{i t}=\alpha_{i}+\beta_{i} \ln G D P p c_{i t}+\varepsilon_{i t} \\
& \ln G G D P_{i t}=\alpha_{i}+\beta_{i} \ln G D P p c_{i t}+\varepsilon_{i t} \\
& \ln G G D P_{i t}=\alpha_{i}+\beta_{i} \ln G D P_{i t}+\varepsilon_{i t}
\end{aligned}
$$

where $G_{i t}$ is real total government spending, GDP is real gross domestic product, GDPpc is real GDP per capita, $G p c$ is real total government spending per capita, GGDP is the ratio of real total government spending to real GDP, $i$ and $t$ are country and time subscripts and $\varepsilon_{i t} \approx N(0, \sigma)$ for all $i$ and $t$. The estimates of $\beta$ represent the income elasticity of national income to government expenditure. Note also that we estimate equations $1-5$ using either GDP or GNP.

Of the very few studies that have a focus on New Zealand, Chang et al. (2004) provide a cross country analysis of the share of government spending and GDP with results generated through unit root tests that imply the presence of variable cointegration, albeit without an income elasticity estimate. The authors employ the Johansen's Maximum Likelihood (JML) technique to estimate equations 1-5 for ten countries over the period 19511996 and assert that income unidirectionally Granger-causes government spending shares for six countries (Japan, South Korea, Taiwan, UK and USA) but that no causal relationship was found for Australia, Canada, South Africa and Thailand and, most noteworthy here, New Zealand.

2 Ahsan et al. (1996) test Wagner's Law (using eqs. 1 and 4) for Canada and obtain coefficient estimates of the income variables between 1.4 and 0.5 , suggesting support for the hypothesis that GDP growth and the relative size of the public sector possess a positive relationship. Biswal et al. (1999) also find bidirectional causality for Canada. Islam (2001) found strong support for Wagner's Law (eq. 1) for the USA with income elasticity estimates of around 0.4 and a Granger-causality from GDP to government expenditure. Kolluri et al. (2000) examine Wagner's Law for the G7 industrialized countries (eq. 1) and present supportive results for Wagner's Law throughout. Sideris (2007) obtains results (eqs. 1-5) that support for the existence of Wagner's Law for Greece. Ghali (1999) analyses ten OECD countries data and shows that government size Granger-causes growth but there is some disparities concerning the proportion by which government size contributes to explaining future changes in the growth rates.

3 Chow et al. (2002) argue (eqs. 1 and 4) that omitted variables may mask or overstate the linkages between government spending and growth and, using the JML technique and UK data for the period 1948-1997, present no evidence to support Wagner's Law until they include the money supply, after which they obtain a unidirectional causality from income and money supply to government spending. Burney (2002) identifies no empirical support (eq. 4) for the validity of Wagner's Law for Kuwait. Courakis et al. (1993) examine Wagner's Law (eq. 1) for Greece and Portugal and provide little supportive evidence for either country. Ansari et al. (1997) examine the relationship between public expenditure and income (eq. 1) for Ghana (1963-1988), Kenya (1964-1989) and South Africa (1957-1990) and failed to find any long run relationship between the two variables for any of the three countries. Sinha (2007) examines the validity of Wagner's Law for Thailand (eqs. 2, 3 and 5) and present little evidence of cointegration between government spending and income and no evidence of causality. 


\section{Methodology}

\section{Model selection and cointegration}

As implied above, a central issue in testing Wagner's Law is the choice of appropriate model specification; this is important because of the possibility of misspecification bias in these types of studies, as highlighted by Peacock and Scott (2000) and Oxley (1994).

Accordingly we follow a two-step strategy where we initially test for cointegration across the suite of equations presented above (eqs. 1-5) using the autoregressive distributed lag (ARDL) bounds test. Effectively here we are following the examples of Ahsan et al. (1996), Biswal et al. (1999), Chang (2002), Chow et al. (2002), Karagianni et al. (2002) and Chang et al. (2004). Although Wagner's Law originally looked at GNP, most studies have used GDP as their income variable. We therefore estimate equations 1-5 and interchangeably use GDP and GNP measures.

As can be seen from Table 2, results from our cointegration estimates indicate that it is only present when we estimate equation 4 , where the cointegration between the share of government expenditure in GDP (GNP) and per capita GDP (GNP) is significant at the 95 percent confidence level. This empirical evidence could indicate three distinct things for the New Zealand economy over this time period: i) that neither the Wagner's nor the Keynesian perspectives were correct, as implied by Chang et al. (2004), ii) that the orders of cointegration were not constant, or iii) that the only correct relationship is as presented in equation 4.

\section{\{Insert Table 2 about here $\}$}

We continue with our analysis by selecting equation 4 as the preferred model to test for a long run relationship between the share of government expenditure in GNP (or GDP) and real per capita income. This model selection is also in line with the models estimated by Ahsan et al. (1996), Burney (2002), Chow et al. (2002), Chang et al. (2004) and Sideris (2007). Our empirical method uses the ARDL bounds test approach developed by Pesaran et al. (2001) which entails estimating the following unrestricted error correction model:

$$
\begin{aligned}
& \Delta \ln G G D P_{t}=a_{o G}+\sum_{i=1}^{n} b_{i G} \Delta \ln G G D P_{t-1}+\sum_{i=1}^{n} c_{i G} \Delta \ln G D P p c_{t-1}+\sigma_{1 G} \ln G G D P_{t-1}+\sigma_{2 G} \ln G D P p c_{t-1}+\varepsilon_{1 t} \\
& \Delta \ln G D P p c_{t}=a_{o Y}+\sum_{i=1}^{n} b_{i Y} \Delta \ln G D P p c_{t-1}+\sum_{i=1}^{n} c_{i Y} \Delta \ln G G D P_{t-1}+\varpi_{1 Y} \ln G D P p c_{t-1}+\varpi_{2 Y} \ln G G D P_{t-1}+\varepsilon_{1 t} \\
& \Delta \ln G G N P_{t}=a_{o G I}+\sum_{i=1}^{n} b_{i G I} \Delta \ln G G N P_{t-1}+\sum_{i=1}^{n} c_{i G I} \Delta \ln G N P p c_{t-1}+\sigma_{1 G I} \ln G G N P_{t-1}+\sigma_{2 G I} \ln G N P p c_{t-1}+\varepsilon_{1 t} \\
& \Delta \ln G N P p c_{t}=a_{o Y I}+\sum_{i=1}^{n} b_{i Y I} \Delta \ln G N P p c_{t-1}+\sum_{i=1}^{n} c_{i Y I} \Delta \ln G G N P_{t-1}+\varpi_{1 Y I} \ln G N P p c_{t-1}+\varpi_{2 Y I} \ln G G N P_{t-1}+\varepsilon_{1 t}
\end{aligned}
$$

where $\ln$ is the natural $\log$ and $\Delta$ is the first difference operator. We use the $F$ tests to test for the existence of long run relationships and when such relationships are found we use the $F$ test to dictate which variable should be normalized. The null hypothesis of no cointegration amongst the variables in equation (6) is $\left(H_{0}: \sigma_{1 G}=\sigma_{2 G}=0\right)$ against the alternative hypothesis $\left(H_{1}: \sigma_{1 G} \neq \sigma_{2 G} \neq 0\right)$, which is referred to as $F_{G}(G G D P \mid G D P p c)$. In equation (7), where real per capita GDP is the endogenous variable, the null hypothesis of no cointegration is $\left(H_{0}: \varpi_{1 Y}=\varpi_{2 Y}=0\right)$ against the alternative $\left(H_{1}: \varpi_{1 Y} \neq \varpi_{2 Y} \neq 0\right)$, which is referred to as 
$F_{Y}(G D P p c \mid G G D P)$. However, in equations (8) and (9) where GNP represents national income the null hypotheses of no cointegration among variables are $\left(H_{0}: \sigma_{1 G G N P}=\sigma_{2 G G N P}=0\right)$ and $\left(H_{0}: \varpi_{1 Y G N P}=\varpi_{2 Y G N P}=0\right)$, respectively, against the alternative hypotheses $\left(H_{1}: \sigma_{1 G G N P} \neq \sigma_{2 G G N P} \neq 0\right)$ and $\left(H_{1}: \varpi_{1 Y G N P} \neq \varpi_{2 Y G N P} \neq 0\right)$, denoted as $F_{G G N P}(G G N P \mid G N P p c)$ and $F_{Y G N P}(G N P p c \mid G G N P)$, respectively.

The $F$ test has a nonstandard distribution which depends upon: i) whether variables included in the ARDL model are to be $I(0)$ or $I(1)$, ii) the number of regressors and iii) whether the ARDL model contains an intercept and/or a trend. Two sets of critical values (CVs) are reported in Pesaran and Pesaran (1997): one set is calculated assuming that all variables included in the ARDL model are $I(1)$ and the other is estimated assuming the variables are $I(0)$. If the computed $F$ values fall outside the inclusive band, a conclusive decision could be drawn without knowing the order of integration of the variables. More precisely, if the empirical analyses show that the estimated $F_{G}($.$) is higher than the upper$ bound of the $\mathrm{CV}$ while $F_{Y}($.$) is lower than the lower bound of the \mathrm{CV}$ then there exists a unique and stable long run relationship. The same applies to $F_{G I}($.$) and F_{Y I}($.$) .$

\section{Granger Causality}

The existence of cointegration implies Granger causality though it does not indicate the direction of causality. To facilitate an analysis of the direction of causality the JML technique is employed to assess the causality direction. Evidence of a cointegrating relationship implies that the Granger causality model should be augmented with a one period lagged error correction term; hence the following models are to be estimated: ${ }^{4}$

$$
\begin{aligned}
& \Delta \ln G G D P_{t}=v+\sum_{i=1}^{n} \theta_{i} \Delta \ln G G D P_{t-1}+\sum_{i=1}^{n} k_{i} \Delta \ln G D P p c_{t-1}+\pi_{1} E C T_{t-1}+\varepsilon_{1 t} \\
& \Delta \ln G D P p c_{t}=v+\sum_{i=1}^{n} k_{i} \Delta \ln G D P p c_{t-1}+\sum_{i=1}^{n} \delta_{i} \Delta \ln G G D P_{t-1}+\pi_{2} E C T_{t-1}+\varepsilon_{2 t} \\
& \Delta \ln G G N P_{t}=v+\sum_{i=1}^{n} \theta_{i} \Delta \ln G G N P_{t-1}+\sum_{i=1}^{n} k_{i} \Delta \ln G N P p c_{t-1}+\pi_{3} E C T_{t-1}+\varepsilon_{3 t} \\
& \Delta \ln G N P p c_{t}=v+\sum_{i=1}^{n} k_{i} \Delta \ln G N P p c_{t-1}+\sum_{i=1}^{n} \delta_{i} \Delta \ln G G N P_{t-1}+\pi_{4} E C T_{t-1}+\varepsilon_{4 t}
\end{aligned}
$$

where the lagged error correction term derived from the long run cointegrating relationship is represented by $E C T_{t-1}$. The serially independent random errors are $\varepsilon_{1 t}, \varepsilon_{2 t}, \varepsilon_{3 t}$ and $\varepsilon_{4 t}$ which have zero means and finite covariance matrices. Causality results are obtained by regressing the respective dependent variables against past values of both itself and other variables, the Schwarz Bayesian Criterion (SBC) is employed to select the optimal lag, $n$, and $X^{2}$ statistics from the causality results are used to identify rejection of the null hypotheses.

4 Engle and Granger (1987) provide a comprehensive discussion of Granger causality tests. 


\section{Empirical Results}

\section{Unit root test}

The ARDL bounds test technique does not generally require knowledge of the order of variable integration; nevertheless we apply the Augmented Dicky Fuller (ADF) (for both levels and their first differences with an intercept and trend) and Phillips Perron (PP) tests for stationarity properties to ensure robustness of our results. These results are reported in Table 3. The ADF and PP tests statistics for the government spending share of GDP $(G N P)$ and output variables do not exceed the critical values in absolute terms. However, when we take the first difference of each of the variables the ADF and PP statistics are higher than the respective critical values in absolute terms, indicating that the level variables are $I(1)$ and their first differences are stationary.

\{Insert Table 3 about here

\section{Cointegration}

Next we investigate the long run relationship between the real government spending share of $G D P(G N P)$ and real GDP $(G N P)$ per capita through the application of the ARDL bounds test technique to equations 6-9. In all cases the SBC criterion indicates a lag length of 2 periods. When $G G D P$ is the dependent variable, the computed $F$ statistic $\left(F_{G}()=7.9196.\right)$ is greater than the upper bound of the 95 percent critical value (4.378) resulting in the rejection of the null hypothesis of no long run relationship.

Similarly, we construct another ECM with GDPpc as the dependent variable. In this case the computed $F$ statistic $\left(F_{Y}()=3.0557.\right)$ is lower than the critical value.

Further when GGNP and GNPpc are selected as dependent variables, the computed $F$ statistic are $F_{G I}()=$.8.834 and $F_{Y I}()=$.2.780 , where the former (latter) is greater (less) than the 95 percent critical confidence values.

These results imply that there exist two long run relationships: i) when $G G D P$ is the dependent variable and $G D P p c$ is the independent variable, and ii) when GGNP is the dependent variable and $G N P p c$ is the independent variable.

\section{Long run elasticities}

Table 4 reports the results of ARDL, GETS, EG, FMOLS and JML cointegration estimates of the income elasticity of the share of government spending in output. The consistent and stable results obtained across the five estimation techniques reveal that per capita income has a positive impact on the share of government spending in output in New Zealand over this time period; this result is consistently statistically significant at the 95 percent confidence level and produces an income elasticity range between 0.56 and 0.84 . The magnitudes of income elasticity imply that a 1 percent increase in per capita income leads to an increase in the share of government spending to national output of between 0.56 and 0.84 percent. Furthermore these results are consistent irrespective of whether GDP or GNP is employed as the income variable, which implies that openness to trade may have minor effects on the share of government spending in national output.

\{Insert Table 4 about here $\}$ 
Our implied income elasticity estimates are comparable to Ahsan et al. (1996) for Canada, Islam (2001) for USA, Kolluri et al. (2000) for the G7 countries and Arpaia and Turrini (2008) for OECD countries. However, our results contrast with those provided by Chang et al. (2004) who found limited evidence to support Wagner's Law for New Zealand.

\section{Granger Causality}

The existence of a long run relationship among the government spending to income ratio and per capita income advocates that there must be Granger causality in at least one direction. To identify the direction of temporal causality we apply the JML based Granger causality tests for both short and long run situations. The $F$ test of the lagged exogenous variables indicates short run causal effects while the long run causal effect is determined by the significance $(t-$ ratio) of the lagged error correction term. These results are shown in Table 5.

\{Insert Table 5 about here $\}$

In the short run, the share of government spending in output is significant at the 95 percent confidence level in the income equation. Similarly, income is significant in the share of government spending equation at the 95 percent confidence level. These results imply a bidirectional Granger-causality in the short run between the share of government spending in output and per capita income.

In contrast the long run results of the Granger causality test provide a coefficient of the lagged error term $\left(E C M_{t-1}\right)$ that is significant at the 95 percent confidence level with the expected negative sign in the share of government spending to output equation, thereby implying that per capita income Granger-causes the share of government spending to output in the long run. ${ }^{5}$ With these findings, we infer that Wagner's Law does hold for the New Zealand economy.

\section{Conclusion}

In this article, we examined Wagner's Law for New Zealand using time series data for the period 1960 to 2007 . The autoregressive distributed lag bounds test technique was used to select the optimal model and these results suggest that there is a cointegrating relationship between the share of government spending in national output and per capita income. To confirm the robustness of the results, we also used GETS, EG, FMOLS and JML techniques. All five methods of estimation provided consistent results concerning the impact of income on shares of government spending in output with income elasticities ranging from 0.56 to 0.84. This implies that a 1 percent increase in per capita income leads to a 0.56 to 0.84 percent increase in the share of government expenditure of income. These results imply that per capita income increases by more than the increase in the share of the government spending in income. Further, we find that inclusion of either GDP or GNP in the model provides fairly consistent results, suggesting that openness of trade may have minor effects on the share of government spending in income for New Zealand. With these findings, we infer that Wagner's Law does hold for the New Zealand economy.

Granger causality tests were used to confirm the causality direction between the variables. In the short run, we find that the share of government spending in income Grangercauses per capita income and vice versa, but in the long run we found statistically significant

5 The endogeneity problem is limited because income is weakly exogenous. 
evidence in favour of per capita income Granger-causing the share of government spending in income, which is consistent with Wagner's Law. Hence, with the current global financial recession, the New Zealand government should be cautious about its present and future spending as extra public spending is unlikely to cause higher income in the long run. The public debt in New Zealand stands at around 23 percent (est. 2008) of GDP, and any further increases would imply that future government spending may be directed towards debt servicing at the expense of expenditure on capital and technology. 


\section{References}

Ahsan, M., Kwan, A. C. C. and Sahni, B. S. (1996) 'Cointegration and Wagner's hypothesis: time series evidence for Canada', Applied Economics, 28, 1055-1058.

Ansari, M. I., Gordon, D. V. and Akuamoah, C. (1997) 'Keynes versus Wagner: public expenditure and national income for three African countries', Applied Economics, 29, 543-550.

Arpaia, A. and Turrini, A. (2008) 'Government expenditure and economic growth in the EU: long run tendencies and short run adjustment,' available at http://ec.europa.eu/economy_finance/publications.

Barker, F.C., Buckle, R.A. and St Clair, R. W. (2008) 'Roles of fiscal policy in New Zealand', New Zealand Treasury Working Paper 02/08, The Treasury

Biswal, B., Dhawan, U. and Lee, H. (1999) 'Testing Wagner versus Keynes using disaggregated public expenditure data for Canada', Applied Economics, 31, 1283-1291.

Burney, N. A. (2002) 'Wagner's hypothesis: evidence from Kuwait using cointegration tests', Applied Economics, 34, 49-57.

Chang, T. (2002) 'An econometric test of Wagner's Law for six countries based on cointegration and error correction modeling techniques', Applied Economics, 34, 1157-1170.

Chang, T., Liu, W. and Caudill, S. (2004) 'A re-examination of Wagner's Law for ten countries based on cointegration and error-correction modeling techniques', Applied Financial Economics, 14, 577-589.

Chow, Y., Cotsomitis, J.A. and Kwan, A.C.C. (2002) 'Multivariate cointegration and causality tests of Wagner's hypothesis: evidence from the UK', Applied Economics, 34, 1671-1677.

Claus, I., Gill, A., Lee, B. and McLellan, N. (2008) 'An empirical investigation of fiscal policy in New Zealand', New Zealand Treasury Working Paper 06/08, The Treasury

Courakis, A. S., Moura-Roque, F. and Tridimas, G. (1993) 'Public expenditure growth in Greece and Portugal: Wagner's Law and beyond', Applied Economics, 25, 125-134.

Engel, R. F. and Granger, C. W. J. (1987) 'Cointegration and error correction representation, estimation and testing', Econometrica, 55, 251-276

Ghali, K. L. (1999) 'Governmenet size and economic growth: Evidence from a multivariate cointegration analysis', Applied Economics 31, 975-987.

International Financial Statistics, December, 2008. IMF CD-ROM (Washington DC: International Monetary Fund).

Islam, A.M. (2001) 'Wagner's Law revisited: cointegration and exogeneity tests for USA', Applied Economics, $8,509-515$.

Karagianni, S., Pempetzoglou M. and Strikou, S. (2002) 'Testing Wagner's Law for the European Union economies', The Journal of Applied Business Research, 18, 107-114

Keynes, J.M. (1936) 'The General Theory of Employment Interest and Money', New York: Harcourt, Brace \& World Inc.

Kolluri, B. R., Panik, M. J. and Wahab, M. S. (2000) 'Government expenditure and economic growth: evidence from G7 countries', Applied Economics, 32, 1059-1068.

Oxley, L. (1994) 'Cointegration, causality and Wagner's Law: a test for Britain 1870-1913', Scottish Journal of Political Economy, 41, 286-297.

Peacock, A. and Scott, A. (2000), 'The curious attraction of Wagner's Law', Public Choice, 102, 1-17

Pesaran, H. M. and Pesaran, B. (1997) Microfit 4.0. Oxford University Press, England.

Pesaran, M.H., Shin, Y. and Smith, R.J. (2001) 'Bounds testing approaches to the analysis of level relationships', Journal of Applied Econometrics, 16, 289-326.

Sideris, D. (2007) 'Wagner's Law in 19th century Greece: a cointegration and causality analysis', Bank of Greece working paper No. 64, Bank of Greece.

Sinha, D. (2007) 'Does the Wagner's Law hold for Thailand? A time series study', available from http://econpapers.repec.org/paper/pramprapa/2560.htm

Tanzi, V. and Schuknecht, L. (2000) 'Public Spending in the 20th Century A Global perspective', Cambridge University Press

The Treasury (2009), New Zealand Economic and Financial Overview 2009, available at http://www.treasury.govt.nz/economy/overview/2009

The Treasury (2008), New Zealand Economic and Financial Overview 2008, available at http://www.treasury.govt.nz/economy/overview/2008

Wagner, A. (1883) 'Three extracts on public finance', in R. A. Musgrave and A. T. Peacock (eds) (1958), Classics in the Theory of Public Finance. London: Macmillan.

World Factbook (2009) https://www.cia.gov/library/publications/the-world-factbook/ 
Table 1: Averages rates of growth

\begin{tabular}{|l|c|c|c|c|c|}
\hline & $\Delta \ln G$ & $\Delta \ln G D P$ & $\Delta \ln G G D P$ & $\Delta \ln G N P$ & $\Delta \ln G G N P$ \\
\hline $1960-1969$ & 2.990 & 1.640 & 1.351 & 1.422 & 0.785 \\
$1970-1979$ & 7.121 & 1.110 & 6.011 & 1.568 & 3.102 \\
$1980-1989$ & 6.019 & 1.914 & 4.873 & 1.802 & 2.554 \\
$1990-1999$ & 1.801 & 2.196 & 0.605 & 1.584 & 1.323 \\
$2000-2007$ & 2.752 & 3.429 & 1.322 & 2.525 & 1.064 \\
$1960-2007$ & 4.220 & 2.052 & 2.928 & 1.887 & 1.772 \\
\hline
\end{tabular}

Table 2: Tests for cointegration ARDL

\begin{tabular}{|l|c|c|c|c|c|}
\hline & Eq.1 & Eq. 2 & Eq. 3 & Eq. 4 & Eq. 5 \\
\hline GDP is used & 3.300 & 1.600 & 1.613 & $7.919^{*}$ & 4.529 \\
\hline GNP is used & 4.187 & 2.020 & 2.431 & $8.834^{*}$ & 2.074 \\
\hline
\end{tabular}

Notes: The critical values at $5 \%$ and $10 \%$ confidence levels are 7.423 and 6.335 , respectively. These values are reported from Pesaran and Pesaran (1997). * represents statistical significance at 5\% confidence levels

Table 3: Results of ADF and PP unit root tests

\begin{tabular}{|l|c|c|c|c|c|c|c|c|}
\hline & $\ln G G D P$ & $\Delta \ln G G D P$ & $\ln G D P p c$ & $\Delta \ln G D P p c$ & $\ln G G N P$ & $\Delta \ln G G N P$ & $\ln G N P p c$ & $\Delta \ln G N P p c$ \\
\hline ADF Statistic & $0.022[0]$ & $5.117[0]$ & $2.314[1]$ & $6.106[0]$ & $2.763[1]$ & $3.980[0]$ & $1.002[1]$ & $5.771[1]$ \\
\hline PP Statistic & $1.558[3]$ & $4.034[4]$ & $1.876[2]$ & $4.074[6]$ & $1.998[3]$ & $3.873[2]$ & $0.632[2]$ & $4.520[3]$ \\
\hline
\end{tabular}

Notes: The ADF and PP critical confidence values at 5\% are 3.521 and 3.519, respectively. The lag lengths for

$\mathrm{ADF}$ and $\mathrm{PP}$ are in parenthesis.

Table 4: Alternative long run estimates

\begin{tabular}{|l|c|c|c|c|c|}
\hline $\begin{array}{l}\text { Dependent } \\
\text { Variable }\end{array}$ & GETS & EG & FMOLS & JML & ARDL \\
\hline $\ln G D P p c$ & $\begin{array}{c}0.829 \\
(19.22)^{*}\end{array}$ & $\begin{array}{c}0.734 \\
(10.22)^{*}\end{array}$ & $\begin{array}{c}0.749 \\
(5.56)^{*}\end{array}$ & $\begin{array}{c}0.561 \\
(2.15)^{*}\end{array}$ & $\begin{array}{c}0.843 \\
(9.31)^{*}\end{array}$ \\
\hline $\ln G N P p c$ & $\begin{array}{c}0.711 \\
(2.27)^{*}\end{array}$ & $\begin{array}{c}0.699 \\
(3.83)^{*}\end{array}$ & $\begin{array}{c}0.703 \\
(7.44)^{*}\end{array}$ & $\begin{array}{c}0.622 \\
(5.72)^{*}\end{array}$ & $\begin{array}{c}0.758 \\
(2.45)^{*}\end{array}$ \\
\hline
\end{tabular}

Notes: The absolute $t$-ratios are reported in parenthesis. Statistical significance at the $5 \%$ confidence level is represented by $*$.

Table 5: Results of Granger causality tests

\begin{tabular}{|l|c|c|c|c|c|}
\hline $\begin{array}{l}\text { Dependent } \\
\text { Variable }\end{array}$ & $\Delta \ln G D P p c_{t}$ & $\Delta \ln G G D P_{t}$ & $\Delta \ln G N P p c_{t}$ & $\Delta \ln G G N P_{t}$ & $E C M_{t-1}$ \\
\hline$\Delta \ln G D P p c_{t}$ & & $\begin{array}{c}-0.738 \\
(4.75)^{*}\end{array}$ & & & 0.029 \\
& & & & & $(1.14)$ \\
\hline$\Delta \ln G G D P_{t}$ & -0.562 & & & -0.022 & \\
\hline$\Delta \ln G N P p c_{t}$ & & & & $(3.28)^{*}$ & $\begin{array}{c}0.112 \\
(0.75)^{*}\end{array}$ \\
\hline$\Delta \ln G G N P_{t}$ & & & -0.341 & & -0.078 \\
& & & $(2.36)^{*}$ & & $(5.63)^{*}$ \\
\hline
\end{tabular}

Notes: Statistical significance at the $5 \%$ confidence level is represented by $*$. 